\title{
Viewpoints: Feeding Mechanics, Diet, and Dietary Adaptations in Early Hominins
}

\author{
David J. Daegling, ${ }^{1 *}$ Stefan Judex, ${ }^{2}$ Engin Ozcivici, ${ }^{3}$ Matthew J. Ravosa, ${ }^{4,5}$ Andrea B. Taylor, ${ }^{6,7}$ \\ Frederick E. Grine, ${ }^{8,9}$ Mark F. Teaford, ${ }^{10}$ and Peter S. Ungar ${ }^{11}$ \\ ${ }^{1}$ Department of Anthropology, University of Florida, Gainesville, FL 32605 \\ ${ }^{2}$ Department of Biomedical Engineering, Stony Brook University, Stony Brook, NY 11794-5281 \\ ${ }^{3}$ Department of Mechanical Engineering, Izmir Institute of Technology, Urla, Izmir 35430, Turkey \\ ${ }^{4}$ Department of Biological Sciences, Aerospace and Mechanical Engineering, University of Notre Dame, Galvin Life \\ Science Center, Notre Dame, IN 46556 \\ ${ }^{5}$ Department of and Anthropology, University of Notre Dame, Galvin Life Science Center, Notre Dame, IN 46556 \\ ${ }^{6}$ Department of Community and Family Medicine, Duke University, Durham, NC 27708 \\ ${ }^{7}$ Department of and Evolutionary Anthropology, Duke University, Durham, NC 27708 \\ ${ }^{8}$ Department of Anthropology, Stony Brook University, Stony Brook, NY 11794-4364 \\ ${ }^{9}$ Department of Anatomical Sciences, Stony Brook University, Stony Brook, NY 11794-4364 \\ ${ }^{10}$ Department of Physical Therapy, High Point University, High Point, NC 27262-3598 \\ ${ }^{11}$ Department of Anthropology, University of Arkansas, Fayetteville, AR 72701
}

\section{KEY WORDS Australopithecus; Paranthropus; finite element; dental microwear; ontogeny}

\begin{abstract}
Inference of feeding adaptation in extinct species is challenging, and reconstructions of the paleobiology of our ancestors have utilized an array of analytical approaches. Comparative anatomy and finite element analysis assist in bracketing the range of capabilities in taxa, while microwear and isotopic analyses give glimpses of individual behavior in the past. These myriad approaches have limitations, but each contributes incrementally toward the recognition of adaptation in the hominin fossil record. Microwear and stable isotope analysis together suggest that australopiths are not united by a single, increasingly specialized dietary adaptation. Their traditional (i.e., morphological) characterization as "nutcrackers" may only apply to a single taxon, Paranthropus robustus. These inferences can be rejected if interpretation of microwear and isotopic data can be shown to be misguided or altogether erroneous. Alternatively, if these
\end{abstract}

sources of inference are valid, it merely indicates that there are phylogenetic and developmental constraints on morphology. Inherently, finite element analysis is limited in its ability to identify adaptation in paleobiological contexts. Its application to the hominin fossil record to date demonstrates only that under similar loading conditions, the form of the stress field in the australopith facial skeleton differs from that in living primates. This observation, by itself, does not reveal feeding adaptation. Ontogenetic studies indicate that functional and evolutionary adaptation need not be conceptually isolated phenomena. Such a perspective helps to inject consideration of mechanobiological principles of bone formation into paleontological inferences. Finite element analysis must employ such principles to become an effective research tool in this context. Am J Phys Anthropol 151:356-371, 2013. (C) 2013 Wiley Periodicals, Inc.
1. Adaptation has been defined as: "A trait that enhances fitness and that arose historically as a result of natural selection for its current biological role" (Lauder, 1996). Using this processual framework, provide a preferred hypothesis of the dietary adaptations of australopithecines including a discussion of foods consumed. Evidence in support of your hypothesis may include specific analyses performed on fossils, analyses of living primates demonstrating relevant functional and/or dietary relationships, comparative analyses of dietary and morphological trends, as well as modeling studies.

A biologist can make any evolutionary speculation seem scientifically acceptable merely by adorning his arguments with the forms and symbols of the theory of natural selection.

—George Williams 1966:21

Adaptation is not always transparent. Williams' concern was that adaptation is an onerous concept, and he lamented that the term has been invoked uncritically and unnecessarily in biological discussions. Lauder's (1996) definition, though succinct, captures the essence of the problem. The distinction between biological role and adaptation is critical (Bock and von Wahlert, 1965; Radinsky, 1985), and because a judgment must be made as to the ecological significance of the trait (so as to infer fitness effects), it makes detection in the paleontological context even more challenging.

*Correspondence to: David Daegling, Department of Anthropology, University of Florida, Gainesville, FL 32605. USA. E-mail: daegling@ufl.edu

Received 11 July 2012; accepted 24 March 2013

DOI: 10.1002/ajpa.22281

Published online in Wiley Online Library

(wileyonlinelibrary.com). 
Methods for inferring adaptation in the paleontological context are diverse, and these are no doubt far from being exhausted. Over the past half-century, a handful of approaches have been repeatedly applied to the question of diet in the australopiths. These include the use of modern analogy (Jolly, 1970; Kinzey, 1974; Cachel, 1976; Szalay, 1975; DuBrul, 1977; Kay and Cartmill, 1977; Peters, 1987), comparative functional morphology and biomechanics (Robinson, 1954; Rak, 1983; Hylander, 1988; Daegling and Grine, 1991; Lucas et al., 2008), dental wear and tear (Wallace, 1973, 1975; Grine, 1981, 1986; Kay, 1981; Ungar, 1991; Scott et al., 2005; Grine et al., 2006a,b; Ungar et al., 2008), dental morphology and allometry (Robinson, 1952; Pilbeam and Gould, 1976; Kay, 1985; Jungers and Grine, 1986; Ungar, 2004), and most recently stable isotope analysis (Sponheimer and Lee-Thorp, 1999; Sponheimer et al., 2005, 2006; Cerling et al., 2010; Copeland et al., 2011). Finite element analysis (FEA) has also recently been touted as "the best means available for evaluating biomechanical hypotheses in extinct taxa" (Strait et al., 2009:2124). None of these myriad perspectives directly addresses hypotheses of adaptation in the sense that Lauder intended. Analogies merely inform us about possible morphological solutions to ecological challenges, wear and isotope studies give some indication about the physical and chemical properties of what was ingested during finite periods over the lifespan, and biomechanical and allometric studies basically tell us about physical performance attributes and constraints (and not necessarily how these features were used by a given organism). Taken together, these distinct approaches can paint a more or less detailed picture of diet, but this only brings us partway to the question of feeding adaptations and selective pressures. At minimum, we would expect if these perspectives can productively inform the question of trophic adaptation, they should provide a suite of inferences that are coherent with one another. There is no disagreement that there are apparent contradictions in the data (Strait et al., 2009; Grine et al., 2010).

Our contention is that the australopith craniofacial "morphotype" is consistent with a variety of dietary regimens, and that the evolution of the craniofacial skeleton in early hominins was not a simple function of increased reliance on hard-object feeding. Microwear and isotopic data are consistent with one another and indicate a relative invariance of diet in East African Paranthropus boisei, whereas diets between South African Australopithecus africanus and $P$. robustus were not homogeneous. Comparison of "gracile" (Australopithecus) versus "robust" (Paranthropus) crania suggest contrasting diets as well (DuBrul, 1977; Rak, 1983), but whether the derived dentofacial complex of Paranthropus represents a specialized or generalized adaptation with respect to food diversity is a matter of legitimate debate (Wood and Strait, 2004; Ungar, 2011).

We need not belabor the point that australopith evolution (under various phylogenetic hypotheses) is characterized by an increased buttressing of the facial skeleton. The central issue is what this buttressing reflects in terms of feeding behavior. Taking Paranthropus boisei as the most derived case, the dietary "signal" of its skull could indicate 1) heavy reliance on hard items such as nuts and seeds (Peters, 1987), 2) heavy reliance on tough, fibrous foods (DuBrul, 1977), or 3) processing a "normal" diet but in significantly greater quantity (Walker, 1981). The first of these requires intermittently high bite forces but not necessarily greater processing in terms of masticatory cycles. The second possibility involves an increased number of masticatory cycles per day with likelihood of higher bite forces, and the third involves more daily chewing cycles but without appreciable change in occlusal forces. Which change in feeding behavior (higher bite forces, repetitive loading, or both) is more likely responsible for the morphology of australopiths? The prudent answer is that we do not know, because both load magnitude and frequency are implicated in bone metabolic activity resulting in increases in bone mass, architecture and properties (Rubin et al., 1990, 1991; Qin et al., 1998; Judex et al., 2006; Ravosa et al., 2007; Ozcivici et al., 2009). Mastication of tough, fibrous foods entails increased cycle number in association with higher occlusal forces (Hylander, 1979b; Weijs and de Jongh, 2009). The possibility that Paranthropus simply ate more of a typical australopith diet (Pilbeam and Gould, 1974) implies a significantly larger body size relative to Australopithecus, and evidence for this is equivocal (Jungers, 1986; McHenry, 1992).

The evidence from mandibular morphology does not allow for distinguishing between feeding adaptations to tough or hard diets (Hylander, 1988; Daegling and Grine, 1991, 2007), despite the fact that the loading environment of the mandible is much better understood than is the remainder of the facial skeleton (Hylander, 1979a, 1984). Indeed, the association of multiple behavioral signals with a single bony feature or response violates the criteria for adaptive inference in the fossil record (Kay and Cartmill, 1977; Lauder, 1996). We therefore advocate an agnostic stance on what facial morphology reveals about specific dietary adaptations. Even among the mandibular evidence for primates, there is a remarkable diversity of corpus shapes associated with hard-object feeding (Hylander, 1979a; Daegling and Grine, 1991; Daegling, 1992; Taylor, 2006; Daegling and McGraw, 2007). This observation suggests that similar feeding challenges do not necessarily have singular morphological solutions.

Previous to their finite element analysis of the Sts 5 cranium of Au. africanus, Strait et al. (2009) argued that the details of the facial stress field in macaques supported a "Large Object Feeding Hypothesis" (Strait et al., 2008), in which resistance to relatively isolated premolar loads potentially explained australopith craniofacial morphology. This hypothesis further stipulated that in $A u$. africanus these ingested objects were stress-resistant (i.e., hard), and Strait et al. (2009) invoked Rak's (1983) descriptive model of facial mechanics as supporting general adaptation to hard foods in australopiths. We argue that the form of an FEA stress field in Sts 5 or any other fossil hominin does not provide unambiguous insight into diet unless it is known what a skeletally "adapted" stress field looks like (Grine et al., 2010). While FEA represents a potentially powerful tool for questions of biomechanical importance, it is by itself relatively impotent for inferring feeding adaptation.

The cuspal morphology and thick enamel of australopith teeth are apparently incongruent with any hypothesis positing a tough (as opposed to hard) diet. Strait et al. $(2008,2009,2010)$ argue that such hypotheses can be discounted because australopith teeth are not well designed for processing displacement-limited (i.e., tough foods). This reasoning, similar to that which they use to 
interpret their FEA models, is essentially an invocation of Rudwick's (1964) "paradigm method" for paleontological inference, where an optimal structure is posited to be the ultimate arbiter of adaptation. While the logic of the paradigm is utilitarian and by extension "adaptive," it ignores the problem and reality of morphological constraint. We concur that Paranthropus molars are suboptimal structures for shredding fibrous items. However, we believe the megadontia, occlusal morphology, and enamel thickness in Paranthropus represent adaptive solutions that are dependent and contingent on not only a range of possible functions, but also the dentition of its precursor. Lungs in cetaceans make no sense whatsoever without understanding their mesonychid ancestors.

In fact, there exists an extant model for premolar "nutcracking" behavior in sooty mangabeys (Daegling et al., 2011). These committed hard-object feeders employ the ingestive strategy hypothesized by Strait et al. (2009) to explain the unique facial skeleton of $A u$. africanus. Strait et al. reasoned that "the facial skeleton of $A u$. africanus is better designed to withstand premolar loads than that of M. fascicularis." (2009:2126). Yet sooty mangabey facial morphology has much more in common with macaques than australopiths, and these monkeys suffer no obvious deleterious consequences for the "poor design" of their facial skeletons (Daegling et al., 2011).

Lauder's definition of adaptation implicitly insists upon the reality of phylogenetic constraint. Adaptation to diet is all too often explored in terms of purely morphological criteria, but primates are adept at circumventing mechanical problems behaviorally (Norconk et al., 2009). It is thus a useful exercise to consider the breadth of australopith feeding adaptations in the context of a phylogenetic bracket, in this case Homo and Pan. Humans and chimpanzees are both impressive in their dietary breadth; they defy categorization other than as omnivores. One observation germane to the question of australopith feeding adaptation is that chimpanzees and humans deal with the problem of ingesting hard objects by solving the mechanical problem before ingestion (Boesch and Boesch, 1982; Wrangham et al., 2003), which has the certain effect of reducing bone strain (Lieberman et al., 2004). It seems plausible (and parsimonious) to assume that australopiths also had the behavioral capacity to circumvent ingestive challenges.

Consideration of paleoecological, morphological, microwear, and isotopic evidence together yields insight into australopith diets even as the identification of a single adaptive signature in the group remains unrealized (Grine et al., 2012). Grine et al.'s (2012) synthesis suggests the following: 1) Ardipithecus and Au. anamensis may not have had dietary specializations significantly different from living great apes; 2) Au. afarensis possesses a craniodental morphology consistent for "heavy mastication" (Kimbel and Delezene, 2009:40), although without evidence for hard object exploitation; 3) Au. africanus appears to have been a fairly eclectic feeder, with fruits, leaves, and perhaps underground storage organs (tubers) being consumed, but without heavy exploitation of hard objects; 4) P. robustus displays derived morphological features suggesting a more demanding diet relative to $A u$. africanus that almost certainly involved exploitation of hard or brittle objects at least seasonally; and 5) Paranthropus boisei, by contrast and despite fitting the morphological paradigm of a "nutcracker," shows no direct evidence of being a hard-object specialist but appears instead to have been more dependent on tougher, more fibrous foods, perhaps specializing on perennial sedges. These findings challenge a purely morphologically-based interpretation that dietary adaptations segregate along the traditional "gracile" (Australopithecus) versus "robust" (Paranthropus) dimension. If morphology provides an unambiguous adaptive signal, then the interpretation of microwear and isotopic data are in error (Strait et al., 2009, 2010). Our view is that researchers have failed to understand the evolutionary significance of australopith craniofacial anatomy.

2. A significant amount of debate has focused on the methods of inferring diet and adaptations in australopithecines. Provide your critical views (both positive and negative) of how 1) finite element, 2) microwear, 3) enamel fracture and chipping, and 4) isotopic analysis contribute (or detract) from our understanding of australopithecines. These comments should include both methodological concerns and where each analytical technique can inform the adaptive pathway outlined above.

The history of paleontological inference in hominin evolution can be understood in terms of the Law of the Instrument: give a scientist an analytical hammer, and the data for every research problem become boxes of nails. Multivariate statistical investigations, once introduced as a promising methodology for biological questions, were applied to numerous problems in hominin evolution (e.g. Day, 1975a; Rightmire, 1972; Robinson and Steudel, 1973; Bilsborough, 1973; Stringer, 1974; McHenry and Corruccini, 1975). Oxnard (1975) urged caution then by noting that the biological meaning of multivariate morphometric distances was yet to be fully appreciated. The warning is germane today with respect to geometric morphometric and finite element studies that are currently popular: the precision of our data is impressive, but their evolutionary significance cannot be discerned within the methods themselves.

\section{Finite element analysis}

Finite element analysis of two-dimensional shells or three-dimensional bodies, when applied correctly, provides complete characterization of stress and strain fields. With the flexibility and modular interface of in silico environments, it is possible to not only simulate mechanical tests of specimens but also to obtain detailed three-dimensional information on the mechanical behavior of any small volume of tissue within them. As with any computational model, FEA-generated results reflect the initially imposed conditions, and given these conditions researchers can investigate how the structure and material of the specimen can be modified to produce "more favorable" stress/strain distributions. For example, during the engineering design phase of a machine, a specific part can be virtually modified to meet the imposed physical demand and reduce or normalize stress/strain fields for better function. Similar to this "design criterion" analogy, FEA of osseous tissues can describe precise loading conditions within them. In contrast to the engineering analogy, however, neither the structural geometry nor the loading conditions that existed before the modeled organism are generally known for fossils. It also needs to be considered that mechanically altered stress/strain distributions may not represent a mechanical improvement (e.g., for structural 
safety) but simply reflect bone's biological response to the imposed mechanical signals (Rubin et al., 1991). Thus, other than invoking a nebulous assumption that bone is responsive to its mechanical environment, the method by itself cannot provide an independent window into adaptation (whether it be dietary, postural, or locomotor). Finite element data must be carefully interpreted in a framework of bone biomechanics and biology if adaptation is to be inferred. Indeed, of the methods discussed here it is the least direct means to infer diet. The attractiveness of FEA is that, in assuming that the skull is responsive to natural selection and that specific (but incompletely known) biomechanical factors are selectively important, morphology should reflect adaptation over evolutionary time. But by Lauder's definition, this requires knowledge of 1 ) the precursor morphology, and 2) details of feeding behavior (the loadcase).

The first of these conditions, a proper baseline control, has yet to be assessed with respect to Sts 5 . Instead, the stress field was compared between a macaque cranium and this $A u$. africanus specimen, and the loadcases examined were three static idealized events. The null hypothesis of this exercise, though never stated explicitly, is that the strain fields of macaque and australopith crania will be identical. Not surprisingly, this null hypothesis was rejected, which would follow based on morphologic-mechanical relations alone, regardless of any biological considerations.

What is the biological underpinning of this null hypothesis? This critical question has not been confronted. The elegant hypothesis developed for the diaphysis of long bones that bone material and structural properties serve to equalize peak stress (or strain) levels within a narrow band of "optimal" magnitudes (Rubin and Lanyon, 1984) is not tenable for the skull (Hylander et al., 1991; Hylander and Johnson, 1992, 1997; Daegling, 2010; Ravosa et al., 2010a), across the skeleton in general (Rubin et al., 1990, 1991), or even for different regions within the diaphysis of a long bone (Judex et al., 1997; Rubin et al., 2013). This potential discrepancy between the skull and long bones may be related to functional differences that preclude an "optimized" strain interval under physiological loads because the skull of many species is exposed to relatively modest loading but must be able to withstand occasional loads orders of magnitude greater (Hylander and Johnson, 1992). It is therefore not surprising that bone cells residing in the skull respond differently from those in long bones (Rawlinson et al., 1995).

The theoretical approach of Strait et al. (2009, 2010) with respect to what features of the stress or strain field are the target of adaptation is not clearly developed. That is, as far as can be discerned, their FEA results are not informed a priori through competing hypotheses; instead, differences in the magnitude and distribution of strain energy and principal strains are assumed to contain the majority of mechanical cues that modulate morphology. Subsequent interpretation is thus not constrained by prior prediction; this shortcoming allows for the argument that-under premolar loading-both higher absolute strain energy (Strait et al., 2009) and lower relative ("scaled") strain energy (Strait et al., 2010 ) in the $A u$. africanus facial skeleton (i.e., relative to Macaca) support a hypothesis of large hard-object feeding. If both observations are invoked as the result of adaptation, it is difficult to envision any comparative finding that could not be retrofitted to a hypothesis of durophagy for this taxon. No criterion of falsification is explicit.

The second requirement for application of FEA to Lauder's prescription is that we understand the selective value of the trait complex. In the context of FEA this means evaluating the putative loadcases. While enumerating every potential feeding loadcase through FEA would be impractical, Strait et al.'s (2008, 2009, 2010) focus on isolated premolar loads may obscure more than enlighten since it emphasizes what is a behavioral oversimplification (a load isolated on a single tooth) to the exclusion of several other possibilities. Had they included an incisal load case in the FEA contrasts, it is likely that the differences between macaque and australopith facial strain would be magnified even further. Under their implicit logic, this difference would also compel an adaptive explanation. Even if the FEA model is entirely valid and accurate, the resulting data are difficult to interpret in regards to mechanical adaptation to diet because of an incomplete knowledge of the specific mechanical parameter (or combination of parameters) to which bone adapts.

What does the spatial distribution of any given parameter of the stress or strain tensor to a given loading condition actually mean? This is not an esoteric concern but is central to understanding the evolution of bone as a tissue. For example, do large values of strain energy density at a specific site mean that 1) additional bone was placed here because the values were even larger before adaptation (the implicit argument of Strait et al., 2009); 2) the modeled loading conditions applied did not occur very often and there was a consequent lack of adaptation to these conditions; or 3) the loading conditions were modeled correctly and occurred frequently but there was no need to adapt because the values stayed within the window in which the bone is indifferent to the magnitude in question? Again, the topology of the stress, strain, or energy fields by themselves does not reveal a process of adaptation.

\section{Microwear}

Dental microwear is one of the few direct ways of determining what foods were eaten by human ancestors. It provides evidence of foods actually processed with the teeth, rather than hypothetically ingested, during an individual's lifetime. While dental microwear is capable of distinguishing among broad dietary categories (see references in Grine et al., 2012), and even recognizing more subtle differences in diets (Teaford and Oyen, 1989; Teaford and Robinson, 1989; Teaford and Glander, 1991, 1996; Teaford and Runestad, 1992; Mainland, 2003; Merceron et al., 2004), the precise causes of those wear patterns have been difficult to pin down.

Despite uncertainties as to the etiology of microwear formation, one regularity is that animals that crush hard, brittle foods typically have complex, pitted occlusal surfaces compared with closely-related taxa that shear tough items (sensu Kay and Hiiemae, 1974), yielding more anisotropic wear surfaces in the latter. This holds whether the comparisons are between primates that masticate tough versus hard foods, or between carnivores that specialize on meat and sinew versus those that chew bone (e.g., Teaford, 1988; Van Valkenburgh et al., 1990; Schubert et al., 2010; Scott et al., 2012). Even so, inference of diet from microwear among primates is challenging given their eclectic feeding habits and 
known seasonal variation, as reflected by overlap in microwear between taxa that differ in some aspects of their diets (Scott et al., 2012).

This knowledge base has been refined through controlled studies on live animals, where diets can be monitored or changed. Such studies have documented the rate of microwear formation as well as elucidated the potential role of exogenous grit in producing wear. The speed of microwear formation is a function of the properties of foods and abrasives ingested (Teaford and Oyen, 1989a; Teaford and Glander, 1991, 1996; Teaford and Tylenda, 1991; Ungar et al., 1995; Teaford and Lytle, 1996; Nystrom et al., 2004; Merceron et al., 2010). Discovery of the rate at which individual microwear features are formed has also led to the realization that microwear will fossilize information on those items consumed shortly before an individual's death-a phenomenon known as the "Last Supper Effect" (Grine, 1986). This is a double-edged sword for paleobiology, because while it allows one to infer diet at uniquely specific points of time, it also raises the possibility that seasonal variation in diet, coupled with differential seasonal mortality, might lead to unrepresentative patterns of microwear being preserved for some species (Kimbel and Delezene, 2009). While such concerns might be intuitively appealing, there is no evidence of primates changing their diets dramatically in the weeks before death unless severe tooth loss precludes the processing of key resources (Cuozzo et al., 2010).

Some workers have eschewed dietary inferences based on microwear because of its potential ephemerality, with the lament that turnover means that traces of rarely eaten, hard fallback foods will not be preserved (Constantino et al., 2009, 2012). Others have criticized microwear because the asymmetry of turnover means that complex textures or surfaces (e.g., those characterized by deep pits and gouges) will have a longer lifespan than non-complex surfaces, leading to an overestimation of hard food consumption (Wood and Schroer, 2012). All else being equal, deep microwear features last longer than shallow ones, but changes in food abrasiveness can eventually lead to the obliteration of deep features (Teaford and Lytle, 1996). From such a perspective, it is then not surprising that molar microwear textures for "habitual hard-food eaters" like Cercocebus atys from the Taï National Park in the Côte d'Ivoire differ from those of "fallback hard-food eaters" like Lophocebus albigena (Daegling et al., 2011). Indeed, differences in microwear texture between $C$. atys from the Taï Forest and a different population of $C$. atys from Liberia (Scott et al., 2012) may reflect fallback, rather than habitual, hard-object feeding in the Liberian mangabeys.

The more pressing challenge is to disentangle the wear processes that lead to particular microwear patterns. Conventional wisdom holds that dental microwear is caused by the abrasion induced by materials (e.g., phytoliths or quartz grains from exogenous dust) being sandwiched between enamel surfaces. However, enamel wear can also result from adhesion, fatigue, erosion and corrosion (Ranjitkar et al., 2008; d'Incau et al., 2012), and a full appreciation of the effects of various chemomechanical processes on enamel wear has yet to be realized. Most work to date has focused on the wear caused by abrasives in or on foods. Abrasive wear can involve relatively large objects causing large-scale fracture, or smaller objects causing scratching and pitting (Lucas et al., 2008). While such size distinctions are useful for modeling wear processes, the actual contact areas for those objects on teeth can be significantly smaller (Roulet, 1987; Walker and Hagen, 1994), which means microwear features may not be created only by small particles.

A frequent misunderstanding behind arguments that food items are either too big or too soft to cause microwear is the notion that the food item itself is solely responsible. Rather, it is the abrasives either in or on a food item that often cause microwear, with feature size, shape, and orientation dependent on whether the abrasives are scraped along a surface (causing striations in the direction of horizontal slip), or pressed into the enamel with force directed normal to that surface (causing pitting) (Gordon, 1971; Maas, 1994; Gügel et al., 2001). In both cases, the relationship between microwear fabrics and diet involves occlusal mechanics, where the angle of approach between opposing teeth is guided, if not dictated by the fracture properties of food items. However, occlusal mechanics may be much more complex than investigators have imagined (Ross et al., 2012), especially if each bite point effectively involves innumerable microscopic points of contact (Roulet, 1987; Radlanski and Jäger, 1989).

Microwear data suggest that the mechanical properties of the foods chosen by Ardipithecus and the early australopiths $A u$. anamensis and $A u$. afarensis were fairly similar, with all three subsisting on a diet that consisted largely of soft or tough foods (Grine et al., 2012). Quantitative analyses for the latter two taxa suggest their diets did not necessarily include the hard objects "predicted" by their morphologies, and the constancy of dental microwear in Au. afarensis suggests either an ability to track its preferred dietary resources across changing habitats, or that environmentally induced shifts in diet did not involve changes in the properties of foods typically consumed (Grine et al., 2006a; Ungar et al., 2010). Microwear on Au. africanus molars suggest a more variable diet than in Au. afarensis. Hypotheses that the diets of $A u$. africanus and $P$. robustus involved differences in the size and quality of the foods eaten have been tested via microwear, and this evidence suggests that $P$. robustus ate smaller objects that required less anterior tooth use, and that it probably resorted to harder foods at times of preferredfood scarcity (Grine, 1981, 1986; Grine and Kay, 1988; Kay and Grine, 1988; Ungar and Grine, 1991; Scott et al., 2005, 2006). Perhaps surprisingly, the microwear fabrics of Paranthropus boisei differ markedly from those of $P$. robustus, implying that these congeners probably had different diets and/or foraging strategies. Whereas some $P$. robustus individuals had wear textures that recall those of extant hard-object specialists (e.g., Cercocebus atys, Table 1), the wear in Paranthropus boisei does not resemble that of animals that chew hard objects. Its microwear fabrics also show remarkable uniformity over time (extending from ca. 2.3 to $1.4 \mathrm{Ma}$ ), much like $A u$ afarensis.

\section{Enamel fracture and chipping}

Tooth chipping has been proposed as an alternative to occlusal microwear as a means by which to reconstruct the diet of extinct animals (Constantino et al., 2009, 2012). Indeed, Strait et al. (2012: 167) have proposed that the first step in testing their hypothesis that $A u$. africanus processed large, hard objects with its 
TABLE 1. Australopith microwear texture complexity: Resampling estimates

\begin{tabular}{lcccc}
\hline Taxon & $N$ & Asfc sample mean & Asfc bootstrap mean & Bootstrap 95\% C.L. \\
\hline Australopithecus afarensis & 19 & 0.740 & 0.741 & $0.637-0.845$ \\
Australopithecus africanus & 10 & 1.522 & 1.522 & $1.303-1.756$ \\
Paranthropus robustus & 9 & 3.543 & 3.543 & $2.638-4.402$ \\
Paranthropus boisei & 8 & 0.585 & 0.585 & $0.425-0.773$ \\
Cercocebus atys & 14 & 4.076 & 4.078 & $3.221-4.961$ \\
\hline
\end{tabular}

Data from Grine et al. (2012) for australopiths and Daegling et al. (2011) for Cercocebus atys sample from Taï Forest, Côte d'Ivoire. Area scale fractal complexity (Asfc) reflects surface roughness changes at different scales of measurement, and assumes larger values in hard object feeding primates (e.g., in addition to Cercocebus atys, Cebus apella $=5.816$, Lophocebus albigena $=2.438$ ) relative to primates with tougher, more folivorous diets (e.g., Alouatta palliata $=0.430$, Trachypithecus cristatus $=0.734$, Gorilla berengei $=1.711)$ (Grine et al., 2012). Data from each taxon were resampled with replacement at original sample sizes over 10,000 iterations; bootstrap means represent the grand mean of the resampled iterations and the confidence interval was determined based on the distribution of resampled means. Only the Paranthropus robustus mean falls within the confidence interval for the habitual hard-object feeder Cercocebus atys, and the confidence intervals of the remaining australopiths and that of Cercocebus atys are non-overlapping. Australopithecus anamensis is excluded from this comparison as bootstrap estimation from such a small sample size $(N=3)$ is unlikely to be meaningful. The values of Asfc for this taxon are 0.808, 1.310, and 0.975.

premolars is "to collect comprehensive information about enamel chip size and frequency in Au. africanus, other hominins and primates." This would be a redundant effort inasmuch as Grine et al. (2010) had, in fact, done just that for $A u$. africanus, and found no evidence for increased chipping on its premolars.

It has been argued that tooth enamel chipping provides a way of "identifying the consumption of rarely eaten foods that dental microwear and isotopic analysis are unlikely to detect" (Constantino et al., 2009: 826). The preference for invoking enamel chips as a dietary indicator is that they are not readily erased by subsequent wear. Since "chipping instantly reveals a history of large hard objects in the diet" (Constantino et al., 2009:826), the argument becomes essentially that an anecdotal event (chipping) is a more reliable dietary indicator than constantly formed, albeit ephemeral events (occlusal microwear).

It has been proposed that one can simply determine the frequency of antemortem enamel chipping in a species sample by counting chipped teeth and computing the incidence against the number of individuals observed (Constantino et al., 2009, 2012; Scott and Winn, 2011). Prior studies of enamel chipping in relation to diet (Robinson, 1956; Tobias, 1967; Wallace, 1973, 1975) were concerned primarily with possible differences between the South African species of Australopithecus and Paranthropus, but their inconclusive results were likely due to the uncertainty about what the incidence of antemortem chipping represents in terms of ingestive behavior (Grine et al., 2010). Incomplete crowns may preserve an enamel chip, but enamel chips that were present on the part of the crown that is missing will be invisible to the record. Thus, the inclusion of incomplete crowns will likely bias results, and (depending upon how much of the crown is missing) this could result in a substantial underestimate of antemortem chipping. Only crowns that are complete should be included in such calculations. Two other variables that confound the calculation of enamel chipping incidences are the size of the tooth crown, and the length of time it has been in service (Grine et al., 2010). All other factors being equal, crowns of overall larger area should be expected to have a greater chance of being chipped, and a tooth that has been exposed to food and the abrasives for a longer period stands a greater chance of exhibiting enamel chipping than a one that has been in use for a shorter period. Another potentially confounding factor is the time elapsed between chip formation and time of death. A chip that formed shortly before death could not be distinguished from one that was created postmortem, and overall crown wear ultimately may lead to chip turnover as the occlusal surface is abraded away. Overall dietary abrasiveness and the rate of gross wear likely play an important role in the identification of antemortem chips.

These factors alone suggest that calculating "chipping frequencies" simply by dividing the number of observed chips by the number of individuals in the sample as by Constantino et al. $(2009,2012)$ will likely result in a biased estimate of chipping in a population. The fact that consecutive studies by Constantino et al. $(2009,2012)$ of postcanine tooth chipping in Gorilla and Pan yielded substantially different results for chimpanzees suggests that these caveats are ignored at peril. In their initial (2010) study, Pan had a chipping frequency of $2.2 \%$, but with the subsequent (2012) addition of the collection in the American Museum of Natural History, the incidence rose to $4.1 \%$. This near doubling of the incidence, owing solely to sample augmentation, is to be expected when chipping frequency equates to the number of individuals in the sample with at least one chipped tooth. Differences in chipping incidences of similar magnitude were recorded by Wallace (1973) and by Grine et al. (2010) for Au. africanus postcanine crowns from the site of Sterkfonteinabout $6 \%$ versus about $11 \%$, respectively. Sampling biases are as likely an explanation as diet (Grine et al., 2010).

The mechanisms of enamel chip formation have been explored theoretically (e.g., Chai and Lawn, 2007a,b; Lucas et al., 2008; Chai et al., 2011; Lee et al., 2011). Lucas et al. (2008) established a size limit of between 2 and $20 \mathrm{~mm}$ for the "large hard objects" that cause chipping (i.e., "large-scale fracture"), and one of 5 to $50 \mu \mathrm{m}$ for the small hard objects responsible for microwear features. The model assumes that these large hard objects have perfectly smooth surfaces. In the real world of nuts and seeds, this is unlikely to be encountered, and we suggest that the actual points of contact between object and tooth are often considerably smaller, perhaps on the order of microns. It follows that if the actual points of contact are generally much smaller than that proposed by Lucas et al. (2008), then most large hard objects will cause scratching and pitting, and chipping will be largely incidental (i.e., from unintended tooth-tooth contacts). 
The relationships proposed between enamel chipping, bite forces, and diet are largely theoretical constructs based upon tests and equations developed on glass, finegrained ceramics, and other synthetic materials (e.g., Chai and Lawn, 2007a,b; Chai et al., 2011). Studies that have been conducted on actual teeth (e.g., Lee et al., 2011) have utilized in vitro experiments on desiccated enamel on tooth crowns in isolation. What is needed is experimental corroboration of these models on teeth under conditions that resemble those in the oral environment.

\section{Stable isotope analysis}

Mineralized tissues bear the chemical signatures of the foods that provided the raw material for their formation. As a result, the study of chemical traces in teeth and bones offers an independent line of evidence by which the diets of extinct hominins can be reconstructed. While chemistry is of considerable value for inferring details about the types of foods eaten during tooth and/ or bone formation, it may offer little (if any) information about food fracture properties or masticatory stresses. Like microwear and dental chipping, mineralized tissue chemistry reflects the actual behavior of an individual at some point during its lifetime and, as such, is also free from the adaptationist assumptions inherent to functional morphology.

Most of the work pertaining to Plio-Pleistocene hominin diet has been based on carbon isotope ratios $\left({ }^{13} \mathrm{C}\right.$ to ${ }^{12} \mathrm{C}$ ) preserved in tooth enamel (see Grine et al., 2012 for a detailed review). Three distinct patterns relating to the carbon isotope signatures of early hominin tooth enamel have emerged from data published to date. Specimens of Ardipithecus ramidus and Australopithecus sediba have low $\delta^{13} \mathrm{C}$ values, in line with savanna chimpanzees, and consistent with the consumption of mostly $\mathrm{C}_{3}$ plants, such as tree-borne items (e.g., leaves and fruits), bushes, and shrubs that would be available in more forested settings (White et al., 2009; Henry et al., 2012). In contrast, fossils of Paranthropus boisei have high $\delta{ }^{13} \mathrm{C}$ values, suggesting the consumption of 75 to $80 \%$ tropical grasses and/or sedges; a dietary level not unlike grass-eating warthogs, hippos and zebras (van der Merwe et al., 2008; Cerling et al., 2011). Finally, early Homo specimens and the South African australopiths, $A u$. africanus and $P$. robustus, generally exhibit intermediate values (Au. africanus is especially variable), indicative of a more catholic diet that included both $\mathrm{C}_{3}$ and $\mathrm{C}_{4}$ resources (e.g., Lee-Thorp et al., 1994, 2010; Sponheimer et al. 2005; van der Merwe et al., 2003, 2008).

Taken in concert, biogeochemistry and microwear can provide potent clues to the dietary proclivities of extinct hominin species (Grine et al., 2012), although their utility has been questioned by those who favor morphological interpretations above other data. Some workers (e.g., Wood and Schroer, 2012) have eschewed evidence from microwear that stands in contradiction to their preferred models of hominin dietary adaptation, but have accepted the validity of equally contradictory evidence from biogeochemical studies. Still others (e.g., Constantino et al., 2009) would maintain that isotopic analyses are also likely to miss important classes of foods, such as fallback resources, because the isotopes reflect only those foods consumed during the period of time during which the enamel was formed.
Owing to the inherently destructive nature of isotope sampling, it is rare for more than a single tooth to be examined for a given individual. In those few instances in which two or three teeth from a single fossil hominin have been sampled (Lee-Thorp et al., 1994; White et al., 2009; Cerling et al., 2011), the data do not indicate any substantial change in diet over time. In any case, isotopic studies cannot detect dietary intake of carbon after the last-forming tooth has completed crown development. In modern humans, this equates to the attainment of adulthood.

Even so, the fact that tooth enamel fossilizes chemical signatures at the time of its development yields a potentially promising area of research. Because of how enamel forms, it is possible to collect minute isotope samples along the growth lamellae on the outer surface of the crown (e.g., Balasse et al., 2003). Sponheimer et al. (2006) and Lee-Thorp et al. (2010) have used laser ablation to document isotopic variation over the period of development of a single tooth in both $A u$. africanus and $P$. robustus, and these studies hint at subtle, seasonal-scale variation in the diets of these individuals. If one can control for the mixing associated with the mineralization phase of enamel formation, such studies hold the potential to track changes in individual food choice throughout the period of tooth-crown formation.

In addition, researchers have looked to the isotopes of other elements for clues to early hominin diets. For example, the relative concentrations of oxygen isotopes $\left({ }^{18} \mathrm{O} /{ }^{16} \mathrm{O}\right)$ in enamel may also provide information about diet and water consumption, due in part to the fact that water molecules made with the lighter ${ }^{16} \mathrm{O}$ will evaporate more quickly than those made with the heavier ${ }^{18} \mathrm{O}$. Unfortunately, as noted by Grine et al. (2012), comparison of data from different sites is hampered by the geographic specificity of local water $\delta^{18} \mathrm{O}$. Additionally, interpretation of the distribution of $\delta^{18} \mathrm{O}$ values among many taxa is still insecure owing to the influence of factors such as drinking behavior, water-use efficiency (e.g., production of variably hyperosmotic urine), evaporative water loss (e.g., panting vs. sweating), thermoregulation, and metabolic rate (Kohn et al., 1996; Sponheimer and Lee-Thorp, 2001; White et al., 2004). Our understanding of $\delta^{18} \mathrm{O}$ patterning in food webs remains very limited (Lee-Thorp, 2008). Nevertheless, there are potentially interesting differences evident among the early hominins. The $\delta^{18} \mathrm{O}$ values for Ardipithecus ramidus are in line with those of other animals at Aramis, whereas those of subsequent hominins (Au. africanus, Paranthropus boisei, and $P$. robustus) are low compared with various herbivores found in the same deposits. This may be related to differences in degree of water dependency among australopiths, but more data are needed (Sponheimer and Lee-Thorp, 1999, 2001; White et al., 2009; Cerling et al., 2011; Grine et al., 2012).

3. Provide a hypothetical view of the diet and morphology of the phylogenetic ancestor of australopithecines. Explain the implications of your hypothesis of dietary adaptations in australopithecines within the phylogenetic context provided by your reconstructed last common ancestor.

Most functional morphologists do (and all should) acknowledge the importance of phylogenetic history in establishing the constraints under which morphology 
could have been adaptively modified by selection (e.g., Harvey and Pagel, 1991; Wenzel and Carpenter, 1994; Martins, 2000; Autumn et al., 2002; Herrel et al., 2004; Metzger and Herrel, 2005; Vincent et al., 2006; O'Neill and Dobson, 2008). Universal consensus on the pattern of hominin phylogeny remains elusive. Indeed, some workers (e.g., Collard and Wood, 2000, 2007) have argued that the craniodental features upon which all such phylogenies are founded are prone to homoplasy and therefore unreliable markers of evolutionary relatedness. Such criticisms have not withstood critical examination (e.g., Strait and Grine, 2001; Gilbert and Rossie, 2007; Gilbert et al., 2009; Gunz, 2012), and the most robustly supported topologies (Strait et al, 1997; Strait and Grine, 2001, 2004; Kimbel et al., 2004) consistently suggest certain relationships among members of the crown clade (e.g., the monophyletic nature of the genera Homo and Paranthropus). While it is possible to employ parsimony to reconstruct some of the character states likely to have been represented at nodes or internodes, such "morphotypes" are chimerical. Speculations concerning ancestry and descent, whether based on perceived morphoclines or some combination of morphology and geochronology, are usually shown to be erroneous upon discovery of new fossils. An example of relevance to the reconstruction of australopith adaptations pertains to the evolutionary history of the "hyperrobust" masticatory package. Cogent arguments based on a suite of morphological features and an elegant functional model of facial transformation led to Au. africanus being recognized as the root of a lineage leading to Paranthropus boisei through $P$. robustus (White et al., 1981; Rak, 1983; Grine, 1984). The discovery of KNM-WT 17000 (the "black skull"), however, effectively removed both South African species from such an ancestral role (Walker et al., 1986; Walker and Leakey, 1988; Kimbel et al., 1988).

Nevertheless, because evolutionary history informs about the structural scaffold upon which selection could have operated to produce adaptive modifications, it is perhaps reasonable to apply a phylogenetic bracket to provide some indication of the basal hominin diet. Given the extant taxa that are most closely related to this clade, this repertoire likely included a range of foods of variable properties, and a number of dietary regimens may have been exploited by the earliest hominins. In this regard, chimpanzees have been commonly employed as the model hominin ancestor (McGrew, 2010), although some (e.g., Sayers and Lovejoy, 2008; Lovejoy, 2009) have taken the position that chimpanzees may be no more appropriate as models than other, more phylogenetically distant taxa, such as platyrrhine monkeys. On the other hand, whether one employs Pan or Ardipithecus or some other taxon as a model, the hard object feeding that is envisioned by Strait et al. (2009, 2012) as having driven australopith evolution necessitates an explanation of how such objects are eaten-seasonally or regularly-by primates (e.g., Pongo, Cercocebus, Sapajus) that do not resemble australopiths in their trophic attributes.

4. What new studies will be most informative for furthering our understanding of australopithecine feeding biology? These may include assessments of methodologies, comparative analyses and/or studies of living primates as models of hominin feeding behaviors. What results from these future analyses would falsify your hypothesis of australopithecine dietary adaptations?
It is instructive to contemplate that a consensus adaptive explanation for the emergence of human bipedalism remains unrealized, a century and a half since Darwin first posed this as a critical question. Functional morphology boasts increasingly powerful technological and statistical tools for understanding biomechanical efficiency and performance, yet identifying adaptation in the paleontological record remains frustrating. We encourage a process-based approach to the problems articulated in the current debate, and welcome experimental demonstrations of enamel chipping, tooth fracture, microwear formation, and iterative finite element investigation (Ross et al., 2005; Strait et al., 2005). What is also critically needed for improving paleontological inferences, perhaps ironically, is more focused investigation into skeletal biology among extant organisms so that the epigenetic and physiological connections between behavior and bone morphology can be elucidated (Bouvier and Hylander, 1981, 1996; Ravosa and Vinyard, 2002; Ravosa et al., 2007, 2008; Menegaz et al., 2009).

\section{Ontogeny and mechanobiology as a window into evolution}

Functional and mechanical hypotheses based on fossil hominin skulls stem largely from comparative analysis of static end-points of development, given the high representation of adults among early hominin fossils. At the same time, it is undeniable that the adult phenotype is the product of complex developmental processes. It is presumably uncontroversial to state that the australopith skull came to be shaped by selective pressures on any number of factors during development (Shea, 1986). Here we provide examples from experimental and neontological comparative approaches to illustrate how an ontogenetic perspective informs adaptive inferences. Our capacity to discern ontogenetic influences on morphology in a paleontological context is limited, but this is hardly an excuse to ignore them. The myriad ways that development shapes adult morphology should persuade us to be circumspect in our conclusions about adaptation in the fossil record.

Phenotypic plasticity is the modulation of development by environment, where the genotype has the ability to produce multiple morphological configurations, physiological states, and/or behaviors (Bernays, 1986; WestEberhard, 2003, 2005). Bone, for example, is often conceptualized as a tissue that is structurally and materially "tuned" to physiological behavior. As a biological tissue, bone is subjected to a lifetime of internal (genetic and epigenetic) and external (environmental) influences that impact the individual phenotype through gene and protein expression during development. In turn, this may condition heritable variation in successive generations via the process of genetic assimilation (Waddington, 1953; Pigliucci et al., 2006). Genetic assimilation provides a conceptual link between functional and evolutionary adaptation.

Bone formation, composition, and architecture are influenced developmentally by dynamic variation in the magnitude and frequency of mechanical loads (Bouvier and Hylander, 1981, 1984, 1996; Lanyon and Rubin, 1985; Biewener et al., 1986; Biewener and Bertram, 1993). While there is evidence of a minimum strain level and frequency required for bone tissue to produce a physiologically adaptive response (Beecher et al., 1983; 
Bouvier and Hylander, 1984; Lanyon and Rubin, 1985), defining what these minimal levels are in terms of thresholds or even the strain variable in question is far from straightforward (Qin et al., 1998, Gross and Srinivasan, 2006). While there is in vivo evidence for mechanism(s) to ensure similarity of peak strains and stresses at homologous sites in organisms of differing body sizes (Lanyon and Rubin, 1985; Biewener, 1991, 1993), there is equally compelling evidence that peak strain values differ significantly between masticatory and locomotor elements and across skeletal sites in general (Ravosa et al., 2010a). Presence of these strain gradients compels the conclusion that there exist local, site-specific controls on the formation and maintenance of bone throughout the skeleton (Goodship et al., 1979; Hylander and Johnson, 1997; Ravosa et al., 2010a). In other words, there is no singular strain or stress threshold that evokes metabolic activity in bone. Consequently, one can more reliably infer function in the fossil record among those skeletal regions for which there is experimental evidence regarding mechanobiological determinants of morphological variation.

Mechanobiological influences on primate craniofacial morphology are not uniform across the skull, as first suggested by study of circumorbital and postorbital septum strains arising from masticatory loads (Hylander et al., 1991; Ross and Hylander, 1996, Ravosa et al., 2000a,b,c). Across a range of primates, significant strain disparities have been demonstrated between maxillomandibular and circumorbital regions of the skull, with the supraorbital region experiencing relatively low strain (Hylander et al., 1991; Ravosa et al., $2000 a, b, c)$. In fact, there is no evidence in vivo or in vitro for a positive response of cortical bone in the cranial vault to varying loading conditions during growth (Rawlinson et al., 1995; Menegaz et al., 2010). These two sets of observations (relatively low strain magnitudes in the circumorbital region and the absence of a load-induced cortical bone response in the cranial vault) have further supported the conclusion that the supraorbital region maintains considerably larger amounts of bone than needed either to resist masticatory loads or to provide safety factors to minimize bone failure (Hylander et al., 1991; Hylander and Johnson, 1997). In other words, the primary determinant of the distribution and amount of bone in the upper face and neurocranium is unlikely to be masticatory forces (Hylander et al., 1991; Ross and Hylander, 1996; Ravosa et al., 2000a,b,c; Lieberman et al., 2004), which calls into question the value of computer or other models that assume circumorbital features are adapted for resisting masticatory stresses (e.g., Bookstein et al., 1999). Apparent links between circumorbital form and dietary properties are likely instead to be indirect consequences of the scaling of structural variation among different cranial components (Moss and Young, 1960; Ravosa, 1988, 1991a,b; Menegaz et al., 2010). Collectively, these studies suggest that it is unwise to proceed from the premise that the entire primate facial skeleton as a unit is first and foremost an adaptation to accommodate masticatory forces.

Waddington (1942) recognized developmental canalization as a selectively advantageous removal of a norm of reaction (or some aspect of it) to an obligate condition. This only smacks of Lamarckian inheritance if the genetic and epigenetic context is ignored, but it does provoke the question of what benefit accrues by removing a component of plasticity in the course of evolution. An example makes this point clearer: in a clade where a given skeletal element has been subjected to elevated loading in an ancestral species, neonates of descendant taxa will exhibit relatively larger homologous structures. It is argued that the reason for this is not that the descendant experiences greater loads prenatally, but that there is a canalized response that anticipates elevated loading during ontogeny much like its ancestors experienced (Trinkaus et al., 1994; Churchill, 1999; Wallace et al., 2010). This example of genetic assimilation suggests that the neonatal disparity in skeletal robusticity between ancestor and descendant provides the functional benefit to ensure similar strains at homologous sites, and thus similar levels of bone formation later in ontogeny (Wallace et al., 2010). Comparative ontogenetic studies support this scenario, in that scaling between close relatives that differ in dietary properties or feeding ecology vary frequently with regard to transpositions of growth allometries for measures of mandibular robusticity and jaw-adductor mechanical advantage (i.e., only $y$-intercept differences: Vinyard and Ravosa, 1998; Ravosa and Daniel, 2010; Ravosa et al., 2010b). This represents the heterochronic phenomenon of predisplacement (Gould, 1966), where selectively advantageous ancestral size:shape covariation relationships are maintained in descendant taxa via an earlier ontogenetic shift in the onset of a given phenotype (Gould, 1971; Dodson, 1975a,b). This obviates selection for divergent growth trajectories between sister taxa. While these findings inform in silico analyses of primate craniomandibular adaptations, interpretation is still complicated by the reality of between-site and clade-specific variation in osteogenic stimuli, as well as potential interspecific variation in reaction norms.

Patterns of phenotypic covariation can be influenced by alteration of food material properties early in ontogeny, with implications for interpretation of adaptive significance in adult skeletal structures (Ravosa et al., 2007, 2008). For example, experimental studies of rabbit ontogeny (Menegaz et al., 2009) support the influence of biomechanical loading on the development of hard palate morphology. In particular, early exposure to elevated masticatory loads and the development of significantly thicker palates provides empirical support for previous hypotheses linking thick palates in Paranthropus to increased loading of the masticatory apparatus (Rak, 1983; contra McCollum, 1997, 1999) and more gracile facial elements related to the cooking of food items (Lieberman et al., 2004).

Claims that functional (= developmental) and evolutionary adaptation, while conceptually separable, are also biologically non-overlapping phenomena, often invoke the incorrect notion that phenotypically plastic or epigenetic responses lack a genetic basis. However, the capacity for plasticity is indeed heritable (Nussey et al., 2005), and phenotypic plasticity facilitates dietary heterogeneity (Mittelbach et al., 1999; see also Robinson and Wilson, 1998). While the relationship between behavioral and phenotypic variation remains a topic of discovery, there is emerging evidence that developmentally plastic responses to altered loads (often of a dietary nature) during ontogeny induce changes in gene- and protein-expression patterns which ultimately affect anatomical and functional variation (Bouvier and Hylander, 1981, 1984, 1996; Beecher et al., 1983; Rawlinson et al., 1995; Mao, 2002; Lieberman et al., 2004; 
Tang and Mao, 2006; Ravosa et al., 2007, 2008, 2009). Importantly, such epigenetic changes can and do influence the phenotype of subsequent generations (Gotthard and Nylin, 1995; Agrawal, 2001; West-Eberhard, 2003, 2005; Pigliucci, 2005).

The quantitative genetics of the plasticity response provide another link between functional and evolutionary adaptation. Diet-induced changes in cranial plasticity during development impact phenotypic covariance patterns which can influence the way heritable variation and natural selection interact to produce evolutionary change at the organismal level (Gupta and Lewontin, 1982; Cheverud et al., 1983; Stearns, 1989). As noted above, lower facial structures such as the mandible and maxilla show osteogenic responses to varying masticatory loads while upper facial elements do not. The implication of this finding is that phenotypic covariance structure differs between lower and upper facial skulls of sister taxa that vary in feeding mechanics. The change in covariance patterns complicates the partitioning of the selection differential (Cheverud, 1989) on ecogeographic variants within species. This might, however, ultimately be beneficial for adaptive inference in the paleoanthropological context. Since variability in postweaning mandibular responses characterizes rabbits subjected to protracted "annual" versus more "seasonal" variation in mechanically challenging diets (Scott et al., 2013), it is conceivable that such neontological data might help to uncover functional signals of "fallback foods" in the fossil record. It is also worth considering in the context of fallback adaptations that the strength of an adaptive signal depends on how long and when an individual uses a given skeletal structure for a specific behavior during its lifetime (Menegaz et al., 2012). It is established that the capacity for plastic changes during an animal's lifetime decreases with age (Hinton and McNamara, 1984; Meyer, 1987; Bouvier, 1988; Rubin et al., 1992; Bouvier and Hylander, 1996; Ravosa et al., 2008). In the paleobiological context, fossil skeletal structures are more likely to reflect behaviors adopted earlier in growth or employed for a longer period of ontogeny. Conversely, it is more difficult to infer behaviors adopted for brief periods or late during life, regardless of their importance to an organism's performance and fitness.

In a final example, we review previous comparative analyses of the scaling of the papionin symphysis to highlight the utility of an ontogenetic allometric perspective for inferring adaptation. In papionins and other anthropoids, symphyseal width appears to represent a structural response to lateral transverse bending of the mandible, in which the lingual symphysis experiences high tensile strains and large stress concentrations (Hylander, 1984, 1985; Hylander et al., 1987, 2000, 2005; Vinyard et al., 2008). Elevated symphyseal stresses can result from the processing of mechanically challenging foods or from allometric increases in symphyseal curvature independent of food material properties. Because mandibular length scales positively relative to mandibular arch width both ontogenetically and interspecifically in papionins (Hylander, 1985; Vinyard and Ravosa, 1998), elevation in stress concentrations along the lingual aspect of the symphysis is predicted due to size-related increases in symphyseal curvature alone. The key insight is that adult interspecific differences in symphyseal curvature may be explained by postnatal changes linked to maintaining functionally equivalent wishboning stress due to allometric increases in symphyseal curvature, independent of the effects of feeding behavior or diet. Were it not for our ability to examine the ontogenetic patterning of symphyseal morphology, the observed differences in adult papionin symphyseal form could easily be misinterpreted as adaptive responses to relatively larger loads associated with harder or tougher diets. The need for considering such factors in the interpretation of craniofacial differences among adult fossil hominins is clear. It is indeed unfortunate that there is not an isometric relationship between skull morphology and diet (whether the latter is measured along dimensions of food geometry, ingestive behavior, or food material properties), but elegance of explanation in preference to biological plausibility cannot be considered a recipe for understanding adaptation.

In short, mechanobiological processes vary ontogenetically and remain incompletely understood. Moreover, allometry can yield robust phenotypes in the absence of dietary variation among sister taxa. Both factors complicate our ability to infer skeletal adaptation in the fossil record via traditional comparative methods, and pose significant challenges for in silico models of craniofacial adaptation from singular and often fragmentary specimens. To be clear, we are not advocating that fossils can only be analyzed in an ontogenetic framework. Rather, we are emphasizing the positive impact that a more diversified perspective incorporating ontogenetic, experimental, and ecomorphological data can have on primate paleobiological reconstructions. Ultimately, a more complete understanding of causal mechanisms driving observed anatomical correlations is our best hope of linking variation in adult phenotypes to adaptations in extant and extinct organisms.

\section{A proposed approach to FEA}

If FEA is to offer insight into adaptation of the craniofacial skeleton in the paleontological context in addition to a description of its mechanical behavior, then its implementation must include an effort to emulate, to some degree, a process of functional or evolutionary adaptation. This will not be easily achieved, but a useful first step to understanding evolutionary adaptation in $A u$. africanus would be to model a potential "predecessor" (perhaps Au. afarensis) to explore changes in craniofacial stress and strain. The problem in comparing Australopithecus with Macaca is that neither taxon evolved into its morphological state from something resembling the other. What might make the comparison reasonable in terms of adaptation would be some assumption that the same specific mechanical parameters drive the spatial distribution of bone in both taxa. But these parameters have not been identified for the skull, and the evidence from long bones indicates that new bone can be deposited in areas of large or small strains (Gross et al., 1997; Judex et al., 1997; Chennimalai Kumar et al., 2010; Sugiyama et al., 2012). One avenue that might offer insight would be an iterative approach in which different hypotheses of bone adaptation are tested explicitly, in terms of substituting different input signals to regulate a defined bone deposition/ resorption algorithm (e.g., Carter and Beaupre, 2001).

An FEA of any specimen represents a biomechanical state-of-being, a static endpoint of a process of skeletal adaptation. It is difficult, given current knowledge, to 
specify what processes led to this state. Assuming a valid model $^{1}$, there are many questions that an FEA approach is well suited to address, including calculation of safety factors and comparison of strain gradients across specimens. It is useful to know how these variables compare among species, but this is only a first step toward understanding what species differences in mechanical performance mean in biological terms. It is not that FEA cannot inform hypotheses of feeding ecology; it is simply that our understanding of skeletal biology is currently inadequate for making a defensible adaptive argument. We should not abandon paleontological application of FEA; instead, we should adjust our expectation about what we can infer from it.

\section{A pragmatic recommendation: Beware the untestable}

Bock (1980) argued that morphology could not be linked intelligibly to adaptation without considering its interaction with environmental variables. In the paleontological context, this presents an enormous challenge. The merits of a Popperian perspective are debatable from an epistemological standpoint (Maxwell, 1972), but insisting upon falsifiability for paleoanthropological hypotheses strikes us as both prudent and productive. For example, the role of fallback foods in hominin evolution has received considerable attention in recent years (Scott et al., 2005; Wrangham et al., 2009; Constantino and Wright, 2009). In the paleoanthropological context, however, such hypotheses have proven to be malleable to a fault since they can survive any number of logical contortions once fallback episodes are deemed "invisible" in the fossil record. The reality of fallback foods as adaptively significant need not be debated, but their invocation in the fossil record must be supported by something other than rationalization (cf. Kimbel and Delezene, 2009; Strait et al., 2009).

History shows that relatively few hominin fossils and an abundance of paleoanthropologists make for hypothesis inflation. The problem for understanding adaptation, however, is not simply a dearth of fossils. How we frame and test hypotheses is probably more important in the short term. The question "what developmental factors underlie the valgus knee?" is more worthy of our attention than the question "why did we walk upright?" (O'Grady, 1986; Lovejoy et al., 1999). An incremental approach to understanding adaptation in the fossil

\footnotetext{
${ }^{1}$ Validity of the Sts 5 model (Strait et al., 2009) remains an open question. Being a fossil, which is resistant to meaningful mechanical testing, its validity hinges on the correctness of the male macaque model with which it is compared. Cause for skepticism is provided by the observation that the strain data for female macaques appear to fit the finite element model better than the corresponding data for male macaques (Grine et al., 2010). In addition, zygomatic arch strain gradients in the finite element model are at odds for those recorded in vivo. Strait et al. (2012) have resolved this problem by reporting agreement between relative in vivo and model strains at two sites on the zygomatic arch, ignoring their own graphic admission that there are also experimental and finite element model data to define a gradient among three such sites. Inclusion of midzygomatic strains originally reported in 2009 in their 2012 reanalysis would reveal a large discordance between in vivo and model strain gradients. The reported anterior zygomatic strains are cited from a paper (Strait et al., 2005) that does not report model strains from this location. Another paper that analyzes the macaque model (Ross et al., 2005) graphically reports a value about half of that reported by Strait et al. (2012) for the anterior zygomatic arch.
}

record might be less exciting but productively restrains our imagination in a field that has, to its detriment, all too rarely reined it in.

\section{ACKNOWLEDGMENTS}

The authors are grateful to the associate editor and an anonymous reviewer for a thorough and cogent critique of an earlier draft of this manuscript. The authors also thank Christopher Ruff for extending the invitation to contribute this perspectives piece.

\section{LITERATURE CITED}

Agrawal AA. 2001. Phenotypic plasticity in the interactions and evolution of species. Science 294:321-326.

Autumn K, Ryan MJ, Wake DB. 2002. Integrating historical and mechanistic biology enhances the study of adaptation. Quart Rev Biol 77:383-408.

Balasse M. 2003. Reconstructing dietary and environmental history from enamel isotopic analysis: time resolution of intratooth sequential sampling. Int J Osteoarchaeol 12:155-165.

Beecher RM, Corruccini RS, Freeman M. 1983. Craniofacial correlates of dietary consistency in a nonhuman primate. J Craniofac Gen Dev Biol 3:193-202.

Bernays EA. 1986. Diet-induced head allometry among foliagechewing insects and its importance for graminivores. Science 231:495-497.

Biewener AA. 1991. Musculoskeletal design in relation to body size. J Biomech 24:19-29.

Biewener AA. 1993. Safety factors in bone strength. Calcif Tissue Int 53:568-574.

Biewener AA, Bertram JEA. 1993. Skeletal strain patterns in relation to exercise training during growth. J Exp Biol 185: 51-69.

Biewener AA, Swartz SM, Bertram JEA. 1986. Bone modeling during growth: dynamic strain equilibrium in the chick tibiotarsus. Calcif Tissue Int 39:390-395.

Bilsborough A. 1973. A multivariate study of evolutionary change in the hominid cranial vault and some evolution rates. J Hum Evol 2:387-403.

Bock WJ, von Wahlert G. 1965. Adaptation and the form-function complex. Evolution 19:269-299.

Bock WJ. 1980. The definition and recognition of biological adaptation. Am Zool 20:217-227.

Boesch C, Boesch H. 1982. Optimisation of nut-cracking with natural hammers by wild chimpanzees. Behaviour 83: 265-286.

Bookstein F, Schafer K, Prossinger H, Seidler H, Fieder M, Stringer C, Weber GW, Arsuaga JL, Slice DE, Rohlf FJ, Recheis W, Mariam AJ, Marcus LF. 1999. Comparing frontal cranial profiles in archaic and modern Homo by morphometric analysis. Anat Rec (New Anat) 257:217-224.

Bouvier M. 1988. Effects of age on the ability of the rat temporomandibular joint to respond to changing functional demands. J Dent Res 67:1206-1212.

Bouvier M, Hylander WL. 1981. Effect of bone strain on cortical bone structure in macaques (Macaca mulatta). J Morphol 167:1-12.

Bouvier M, Hylander WL. 1984. The effect of dietary consistency on gross and histologic morphology in the craniofacial region of young rats. Am J Anat 170:117-126.

Bouvier M, Hylander WL. 1996. Strain gradients, age, and levels of modeling and remodeling in the facial bones of Macaca fascicularis. In: Davidovitch Z, Norton LA, editors. The biological mechanisms of tooth movement and craniofacial adaptation. Boston: Harvard Society for the Advancement of Orthodontics. p 407-412.

Cachel S. 1976. A new view of speciation in Australopithecus. In: Tuttle RH, editor. Paleoanthropology. The Hague: Mouton. p 183-210.

Carter DS, Beaupre GS. 2001. Skeletal form and function. Cambridge: Cambridge University Press. 
Cerling TE, Mbua E, M'Kirera F, Manthi FK, Grine FE, Leakey MG, Sponheimer M, Uno KT. 2011. Diet of Paranthropus boisei in the early Pleistocene of East Africa. Proc Natl Acad Sci USA 108:9337-9341.

Chai H, Lawn BR. 2007a. A universal relation for edge chipping from sharp contacts in brittle materials: a simple means of toughness evaluation. Acta Mater 55: 2555-2561.

Chai H, Lawn BR. 2007b. Edge chipping of brittle materials: effect of side-wall inclination and loading angle. Int J Fracture 145: 159-165.

Chai H, Lee JJW, Lawn BR. 2011. On the chipping and splitting of teeth. J Mech Behav Biomed Mat 4: 315-321.

Chennimalai Kumar N, Dantzig JA, Jasiuk IM, Robling AG, Turner CH. 2010. Numerical modeling of long bone adaptation due to mechanical loading: correlation with experiments. Ann Biomed Eng 38:594-604.

Cheverud JM. 1989. A comparative analysis of morphological variation patterns in the papionins. Evol 43:1737-1747.

Cheverud, JM, Rutledge JJ, Atchley WR. 1983. Quantitative genetics of development: genetic correlations among age-specific trait values and the evolution of ontogeny. Evol 37: 895-905.

Churchill SE. 1999. Cold adaptation, heterochrony, and Neandertals. Evol Anthropol 7:46-60.

Collard M, Wood BA. 2000. How reliable are human phylogenetic hypotheses? Proc Natl Acad Sci USA 97:5003-5006.

Collard M, Wood BA. 2007. Hominin homoiology: an assessment of the impact of phenotypic plasticity on phylogenetic analyses of humans and their fossil relatives. J Hum Evol 52: $573-584$.

Constantino PJ, Wright BW. 2009. The importance of fallback foods in primate ecology and evolution. Am J Phys Anthrop 140: 599-602.

Constantino PJ, Lee JJW, Chai H, Zipfel B, Ziscovici C, Lawn BR, Lucas PW. 2010. Tooth chipping can reveal the diet and bite forces of fossil hominins. Biol Lett 6: 826-829.

Constantino, PJ, Markham, K, Lucas, PW (2012). Tooth chipping as a tool to reconstruct diets of great apes (Pongo, Gorilla, Pan). Int J Primatol 33:661-672.

Copeland SR, Sponheimer M, de Ruiter DJ, Lee-Thorp JA, Codron D, le Roux PJ, Grimes V, Richards MP. 2011. Strontium isotope evidence for landscape use by early hominins. Nature 474:76-78.

Cuozzo FP, Sauther ML, Gould L, Sussman RW, Villers LM, Lent C. 2010. Variation in dental wear and tooth loss among known-aged, older ring-tailed lemurs (Lemur catta): a comparison between wild and captive individuals. Am J Primatol 72:1026-1037.

Daegling DJ. 1992. Mandibular morphology and diet in the genus Cebus. Int J Primatol 13:545-570.

Daegling DJ. 2010. Understanding skull function from a mechanobiological perspective. In: Larsen CS, editor. A companion to biological anthropology. Oxford: Wiley-Blackwell. p 501-515.

Daegling DJ, Grine FE. 1991. Compact bone distribution and biomechanics of early hominid mandibles. Am J Phys Anthropol 86:321-339.

Daegling DJ, Grine FE. 2007. Mandibular biomechanics and the paleontological evidence for the evolution of human diet. In: Ungar PS, editor. The evolution of human diet: the known, the unknown, and the unknowable. Oxford: Oxford University Press. p 77-105.

Daegling DJ, McGraw WS. 2007. Functional morphology of the mangabey mandibular corpus: relationship to dental specializations and feeding behavior. Am J Phys Anthropol 134: $50-62$.

Daegling DJ, McGraw WS, Ungar PS, Pampush JD, Vick AE, Bitty EA. 2011. Hard object feeding in sooty mangabeys (Cercocebus atys) and the interpretation of early hominin feeding ecology. PLoS One 6:e23095.

Day MH. 1967. Olduvai hominid 10: a multivariate analysis. Nature 215:323-324.

Dodson P. 1975a. Taxonomic implications of relative growth in lambeosaurine hadrosaurs. Syst Zool 24:37-54.
Dodson P. 1975b. Relative growth in two sympatric species of Sceloporus. Am Midland Nat 94:421-450.

d'Incau E, Couture C, Maureille B. 2012. Human tooth wear in the past and the present: tribological mechanisms, scoring systems, dental and skeletal compensations. Arch Oral Biol 57:214-229.

DuBrul EL. 1977. Early hominid feeding mechanisms. Am J Phys Anthropol 47:305-320.

Gilbert CC, Rossie, JB. 2007. Congruence of molecules and morphology using a narrow allometric approach. Proc Natl Acad Sci USA 104:11910-11914.

Gilbert CC, Frost SR, Strait DS. 2009. Allometry, sexual dimorphism, and phylogeny: a cladistic analysis of extant papionins using craniodental data. J Hum Evol 57:298-320.

Goodship AE, Lanyon LE, McFie H. 1979. Functional adaptation of bone to increased stress. An experimental study. J Bone Joint Surg 61:539-546.

Gould SJ. 1966. Allometry and size in ontogeny and phylogeny. Biol Rev 41:587-640.

Gould SJ. 1971. Geometric similarity in allometric growth: a contribution to the problem of scaling in the evolution of size. Am Nat 105:113-136.

Gordon KD. 1982. A study of microwear on chimpanzee molars: implications for dental microwear analysis. Am J Phys Anthropol 59:195-215.

Gotthard K, Nylin S. 1995. Adaptive plasticity and plasticity as an adaptation: a selective review of plasticity in animal morphology and life history. Oikos 74:3-17.

Grine FE. 1981. Trophic differences between 'gracile' and 'robust' australopithecines: a scanning electron microscope analysis of occlusal events. S Afr J Sci 77:203-230.

Grine FE. 1984. Australopithecine evolution: the deciduous dental evidence. In: Delson E, editor. Ancestors: the hard evidence. New York: Alan R. Liss. p 153-167.

Grine FE. 1986. Dental evidence for dietary differences in Australopithecus and Paranthropus: a quantitative analysis of permanent molar microwear. J Hum Evol 15:783-822.

Grine FE, Judex S, Daegling DJ, Ozcivici E, Ungar PS, Teaford MF, Sponheimer M, Scott J, Scott RS, Walker A. 2010. Craniofacial biomechanics and functional and dietary inferences in hominin paleontology. J Hum Evol 58:293-308.

Grine FE, Kay RF. 1988. Early hominid diets from quantitative image analysis of dental microwear. Nature 333:765-768.

Grine FE, Sponheimer M, Ungar PS, Lee-Thorp J, Teaford, MF. 2012. Dental microwear and stable isotopes inform the paleoecology of extinct hominins. Am J Phys Anthropol 148: 285-317.

Grine FE, Ungar PS, Teaford MF, El-Zaatari S. 2006a. Molar microwear in Praeanthropus afarensis: evidence for dietary stasis through time and under diverse paleoecological conditions. J Hum Evol 51:297-319.

Grine FE, Ungar PS, Teaford MF. 2006b. Was the Early Pliocene hominin 'Australopithecus' anamensis a hard object feeder? S Afr J Sci 102:301-310.

Gross TS, Srinivasan S. 2006. Building bone through exercise: could less be more? Br J Sports Med 40:2-3.

Gross TS, Edwards JL, McLeod KJ, Rubin CT. 1997. Strain gradients correlate with sites of periosteal bone formation. J Bone Miner Res 12:982-988.

Gügel IL, Grupe G, Kunzelmann KH. 2001. Simulation of dental microwear: characteristic traces of opal phytoliths give clues to ancient human dietary behavior. Am J Phys Anthropol 114:124-138.

Gunz P. 2012. Evolutionary relationships among robust and gracile australopiths: an "evo-devo" perspective. Evol Biol 39: 472-487.

Gupta AP, Lewontin RC. 1982. A study of reaction norms in natural populations of Drosophila pseudoobscura. Evolution 36:934-948.

Harvey PH, Pagel MD. 1991. The comparative method in evolutionary biology. New York: Oxford University Press.

Henry AG, Ungar PS, Passey BH, Sponheimer M, Rossouw L, Bamford M, Sandberg P, de Ruiter DJ, Berger L. 2012. The diet of Australopithecus sediba. Nature 487:90-93. 
Herrel A, Vanhooydonc B, van Damm R.Omnivory in lacertid lizards: adaptive evolution or constraint? J Evol Biol 17: 974-984.

Hinton RJ, McNamara JA Jr. 1984. Temporal bone adaptations in response to protrusive function in juvenile and young adult rhesus monkeys (Macaca mulatta) Eur J Orthod 6:155-174.

Hylander WL. 1979a. The functional significance of primate mandibular form. J Morphol 160:223-239.

Hylander WL. 1979b. Mandibular function in Galago crassicaudatus and Macaca fascicularis: an in vivo approach to stress analysis of the mandible. J Morphol 159:253-296.

Hylander WL. 1984. Stress and strain in the mandibular symphysis of primates: a test of competing hypotheses. Am J Phys Anthropol 64:1-46.

Hylander WL. 1985. Mandibular function and biomechanical stress and scaling. Am Zool 25:315-330.

Hylander WL. 1988. Implications of in vivo experiments for interpreting the functional significance of "robust" australopithecine jaws. In: Grine FE, editor. Evolutionary history of the "robust" australopithecines. New York: Aldine de Gruyter. p 55-83.

Hylander WL, Johnson KR. 1992. Strain gradients in the craniofacial region of primates. In: Davidovitch A, editor. The biological mechanisms of tooth movement and craniofacial adaptation. Columbus, OH: The Ohio State University College of Dentistry. p 559-569.

Hylander WL, Johnson KR. 1997. In vivo bone strain patterns in the zygomatic arch of macaques and the significance of these patterns for functional interpretations of craniofacial form. Am J Phys Anthropol 102:203-232.

Hylander WL, Johnson KR, Crompton AW. 1987. Loading patterns and jaw movements during mastication in Macaca fascicularis: a bone-strain, electromyographic and cineradiographic analysis. Am J Phys Anthropol 72:287-314.

Hylander WL, Picq PG, Johnson KR. 1991. Masticatory-stress hypotheses and the supraorbital region of primates. Am J Phys Anthropol 86:1-36.

Hylander WL, Ravosa MJ, Ross CF, Wall CE, Johnson KR. 2000. Symphyseal fusion and jaw-adductor muscle force: an EMG study. Am J Phys Anthropol 112:469-492.

Hylander WL, Wall CE, Vinyard CJ, Ross CF, Ravosa MJ, Williams SH, Johnson KR. 2005. Temporalis function in anthropoids and strepsirrhines: an EMG Study. Am J Phys Anthropol 128:35-56.

Jolly CJ. 1970. The seed-eaters: a new model of hominid differentiation based on a baboon analogy. Man 5:5-26.

Judex S, Gross TS, Zernicke RF. 1997. Strain gradients correlate with sites of exercise-induced bone-forming surfaces in the adult skeleton. J Bone Miner Res 12:1737-1745.

Judex S, Lei X, Han D, Rubin C. 2006. Low-magnitude mechanical signals that stimulate bone formation in the ovariectomized at are dependent on the applied frequency but not on the strain magnitude. J Biomech 40:1333-1339.

Jungers WL, Grine FE. 1986. Dental trends in the australopithecines: the allometry of mandibular molar dimensions. In: Wood B, Martin L, Andrews P (eds). Major Topics in Primate and Human Evolution. Cambridge: Cambridge University Press. pp 203-219.

Jungers WL. 1988. New estimates of body size in australopithecines. In: Grine FE, editor. Evolutionary history of the 'robust' australopithecines. New York: Aldine de Gruyter. p 115-132.

Kay RF, Cartmill M. 1977. Cranial morphology and adaptations of Palaechthon nacimienti and other Paromomyidae (Plesiadapoidea,?Primates), with a description of a new genus and species. J Hum Evol 6:19-35.

Kay RF. 1981. The nut-crackers -a new theory of the adaptations of the Ramapithecinae. Am J Phys Anthropol 55: 141-151.

Kay RF, Hiiemae KL. 1974. Jaw movement and tooth use in recent and fossil primates. Am J Phys Anthropol 40:227-256.

Kay, RF, Grine FE. 1988. Tooth morphology, wear and diet in Australopithecus and Paranthropus from southern Africa. In:
Grine FE, editor. Evolutionary history of the "robust" australopithecines. New York: Aldine de Gruyter. p 427-448.

Kimbel WH, White TD, Johanson DC. 1988. Implications of KNM-WT 17000 for the evolution of "robust" Australopithecus. In: Grine FE, editor. Evolutionary history of the "robust" australopithecines. New York: Aldine de Gruyter. p 259-268.

Kimbel, WH, Rak, Y, Johanson DC. 2004. The Skull of Australopithecus afarensis. Oxford University Press, New York.

Kimbel WH, Delezene LK. 2009. "Lucy" redux: a review of research on Australopithecus afarensis. Yearb Phys Anthropol $52: 2-48$.

Kinzey WG.1974. Ceboid models for the evolution of hominoid dentition. J Hum Evol 3:191-203.

Kohn MJ, Schoeninger MJ, Valley JW. 1996. Herbivore tooth oxygen isotope compositions: effects of diet and physiology. Geochim Cosmochim Acta 60:3889-3896.

Lanyon LE, Rubin CT. 1985. Functional adaptation in skeletal structures. In: Hildebrand M, Bramble DM, Liem KF, Wake DB, editors. Functional vertebrate morphology. Cambridge: Harvard University Press. p 1-25.

Lauder GV. 1996. The argument from design. In: Rose MR, Lauder GV, editor. Adaptation. San Diego: Academic Press. p 55-91.

Lee JJW, Constantino P, Lucas P, Lawn B. 2011. Fracture in teeth-a diagnostic for inferring tooth function and diet. Biol Rev 86:959-974.

Lee-Thorp JA. 2008. On isotopes and old bones. Archaeometry 50:925-950.

Lee-Thorp JA, van der Merwe NJ, Brain CK. 1994. Diet of Australopithecus robustus at Swartkrans from stable carbon isotopic analysis. J Hum Evol 27:361-372.

Lee-Thorp JA, Sponheimer M, Passey BH, de Ruiter DJ, Cerling TE. 2010. Stable isotopes in fossil hominin tooth ename suggest a fundamental dietary shift in the Pliocene. Phil Trans R Soc B 365:3389-3396.

Lieberman DE, Krovitz GE, Yates, FW, Devlin M, St. Claire M. 2004. Effects of food processing on masticatory strain and craniofacial growth in a retrognathic face. J Hum Evol 46 655-677.

Lovejoy CO. 2009. Reexamining human origins in light of Ardipithecus ramidus. Science 326:74e1-74e8.

Lovejoy CO, Cohn MJ, White TD. 1999. Morphological analysis of the mammalian postcranium: a developmental perspective. Proc Natl Acad Sci USA 96:13247-13252.

Lucas PW, Constantino P, Wood B, Lawn B. 2008. Dental enamel as a dietary indicator in mammals. Bioessays 30: 374-385.

Maas MC. 1994. A scanning electron-microscope study of in vivo abrasion of mammalian tooth enamel under compressive loads. Arch Oral Biol 39:1-11.

Mainland IL. 2003. Dental microwear in grazing and browsing Gotland sheep (Ovis aries) and its implications for dietary reconstruction. J Archaeol Sci 30:1513-1527.

Mao JJ. 2002. Mechanobiology of craniofacial sutures. J Dent Res 81:810-816.

Martins EP. 2000. Adaptation and the comparative method. Trends Ecol Evol 15: 296-299.

Maxwell N. 1972. A critique of Popper's views on scientific method. Philos Sci 39:131-152.

McCollum MA. 1997. Palatal thickening and facial form in Paranthropus: examination of alternative developmental methods. Am J Phys Anthropol 103:375-392.

McCollum MA. 1999. The robust australopithecine face: a morphogenetic perspective. Science 284:301-305.

McGrew WC. 2010. In search of the last common ancestor: new findings on wild chimpanzees. Philos Trans R Soc B 365: 3267-3276.

McHenry HM, Corruccini RS. 1975. Multivariate analysis of early hominid pelvic bones. Am J Phys Anthropol 43:263-270.

McHenry HM. 1992. Body size and proportions in early hominids. Am J Phys Anthropol 87:407-431.

Menegaz RA, Sublett SV, Figueroa SD, Hoffman TJ, Ravosa MJ. 2009. Phenotypic plasticity and function of the hard palate in growing rabbits. Anat Rec 292:277-284. 
Menegaz RA, Sublett SV, Figueroa SD, Hoffman TJ, Ravosa MJ, Aldridge K. 2010. Evidence for the influence of diet on cranial form and robusticity. Anat Rec 293:630-641.

Menegaz RA, Szczodroski AF, Rold TL, Hoffman TJ, Ravosa MJ. 2012. Chewing on something new: an experimental model for primate dietary variability. Am J Phys Anthropol Suppl 54:213.

Merceron G, Viriot L, Blondel C. 2004. Tooth microwear pattern in roe deer (Capreolus capreolus L.) from Chizé (Western France) and relation to food composition. Small Rum Res 53: 125-132.

Merceron G, Escarguel G, Angibault JM, Verheyden-Tixier H. 2010. Can dental microwear textures record inter-individual dietary variations? PLoS One 5:e9542.

Metzger KA, Herrel A. 2005. Correlation between lizard cranial shape and diet: a quantitative, phylogenetically informed analysis. Biol J Linn Soc 86:433-466.

Mittelbach GG, Osenberg CW, Wainwright PC. 1999. Variation in feeding morphology between pumpkinseed populations: phenotypic plasticity or evolution? Evol Ecol Res 1: $111-128$.

Moss ML, Young RW. 1960. A functional approach to craniology. Am J Phys Anthropol 18:281-292.

Norconk MA, Wright BW, Conklin-Brittain NL, Vinyard CJ. 2009. Mechanical and nutritional properties of food as factors in platyrrhine dietary adaptations. In: Garber PA, Estrada A, Bicca-Marques JC, Heymann E, Strier K, editors. South American primates: testing new theories in the study of primate behavior, ecology, and conservation. New York: Springer. p $279-319$.

Nussey DH, Postma E, Gienapp P, Visser ME. 2005. Selection on heritable phenotypic plasticity in a wild bird population. Science 310:304-306.

Nystrom P, Phillips-Conroy JE, Jolly CJ. 2004. Dental microwear in Anubis and hybrid baboons (Papio hamadryas, sensu lato) living in Awash National Park, Ethiopia. Am J Phys Anthropol 125:279-291.

O'Grady RT. 1986. Historical processes, evolutionary explanations, and problems with teleology. Can J Zool 64 $1010-1020$

O'Neill MC, Dobson SD. 2008. The degree and pattern of phylogenetic signal in primate long bone structure. J Hum Evol 54: 309-322.

Oxnard CE. 1975. Uniqueness and diversity in human evolution. Chicago: University of Chicago Press.

Ozcivici E, Luu YK, Adler B, Qin Y-X, Rubin J, Judex S, Rubin CT. 2009. Mechanical signals as anabolic agents in bone. Nature Rev Rheumatol 6:50-59.

Peters CR. 1987. Nut-like oil seeds: food for monkeys, chimpanzees, humans, and probably ape-men. Am J Phys Anthropol 73:333-363.

Pigliucci M. 2005. Evolution of phenotypic plasticity: where are we going now? Trends Ecol Evol 20:481-486.

Pigliucci M, Murren CJ, Schlichting CD. 2006. Phenotypic plasticity and evolution by genetic assimilation. J Exp Biol 209: 2362-2367.

Pilbeam DR, Gould SJ. 1974. Size and scaling in human evolution. Science 186:892-901.

Qin Y-X, Rubin CT, McLeod KJ. 1998. Nonlinear dependence of loading intensity and cycle number in the maintenance of bone mass and morphology. J Orthop Res 16:482-489.

Radinsky LB. 1985. Approaches in evolutionary morphology: a search for patterns. Ann Rev Ecol Syst 16:1-14.

Radlanski RJ, Jäger A. 1989. Zur mikromorphologie der approximalen Kontaktflächen und der okklusalen Schliffacetten menschlicher Zähne. Dtsch Zahnärztl Z 44:196-197.

Ranjitkar S, Kaidonis JA, Townsend GC, Vu AM, Richards LC. 2008. An in vitro assessment of the effect of load and $\mathrm{pH}$ on wear between opposing enamel and dentine surfaces. Archaeol Oral Biol 53:1011-1016.

Rak Y. 1983. The australopithecine face. New York: Academic.

Ravosa MJ. 1988. Browridge development in Cercopithecidae: a test of two models. Am J Phys Anthropol 76:535-555.
Ravosa MJ. 1991a. Ontogenetic perspective on mechanical and nonmechanical models of primate circumorbital morphology. Am J Phys Anthropol 85:95-112.

Ravosa MJ. 1991b. Interspecific perspective on mechanical and nonmechanical models of primate circumorbital morphology. Am J Phys Anthropol 86:369-396.

Ravosa MJ, Daniel AN. 2010. Ontogeny and phyletic size change in living and fossil lemurs. Am J Primatol 72: 161-172.

Ravosa MJ, Vinyard CJ. 2002. On the interface between ontogeny and function. In: Plavcan JM, Kay RF, Jungers WL, van Schaik CP, editors. Reconstructing behavior in the primate fossil record. New York: Plenum Press. p 73-111.

Ravosa MJ, Johnson KR, Hylander WL. 2000a. Strain in the galago facial skull. J Morphol 245:51-66.

Ravosa MJ, Vinyard CJ, Hylander WL. 2000b. Stressed out: masticatory forces and primate circumorbital form. Anat Rec (New Anat) 261:173-175.

Ravosa MJ, Noble VE, Hylander WL, Johnson KR, Kowalski EM. 2000c. Masticatory stress, orbital orientation and the evolution of the primate postorbital bar. J Hum Evol 38: 667-693.

Ravosa MJ, Kunwar R, Stock SR, Stack MS. 2007. Pushing the limit: masticatory stress and adaptive plasticity in mammalian craniomandibular joints. J Exp Biol 210:628-641.

Ravosa MJ, López EK, Menegaz RA, Stock SR, Stack MS, Hamrick MW. 2008. Adaptive plasticity in the mammalian masticatory complex: You are what, and how, you eat. In: Vinyard CJ, Ravosa MJ, Wall CE, editors. Primate craniofacial biology and function. New York: Springer Academic Publishers. p 293-328.

Ravosa MJ, Ning J, Menegaz RA, Stack MS, Schultz G. 2009. Masticatory stress and the functional genomics of the TMJ articular disc in mammals. Am J Phys Anthropol Suppl 48: 337.

Ravosa MJ, Ross CF, Williams SH, Costley DB. 2010a. Allometry of masticatory loading parameters in mammals. Anat Rec 293A:557-571.

Ravosa MJ, Daniel AN, Costley DB. 2010b. Allometry and evolution in the galago skull. Folia Primatol 81:177-196.

Rawlinson SCF, Mosley JR, Suswillo RFL, Pitsillides AA, Lanyon LE. 1995. Calvarial and limb bone cells in organ and monolayer culture do not show the same early responses to dynamic mechanical strain. J Bone Miner Res 10:1225-1232.

Rightmire GP. 1972. Multivariate analysis of an early hominid metacarpal from Swartkrans. Science 176:159-161.

Robinson BW, Wilson DS. 1998. Optimal foraging, specialization, and a solution to Liem's paradox. Am Nat 151: 223-235.

Robinson JT. 1954. Prehominid dentition and hominid evolution. Evolution 8:324-334.

Robinson, JT. 1956. The dentition of the Australopithecinae. Transvaal Museum Memoir, 9. Pretoria: Transvaal Museum.

Robinson JT, Steudel K. 1973. Multivariate discriminant analysis of dental data bearing on early hominid affinities. J Hum Evol 2:509-527.

Ross CF, Hylander WL. 1996. In vivo and in vitro bone strain in the owl monkey circumorbital region and the function of the postorbital septum. Am J Phys Anthropol 101:183-215.

Ross CF, Patel BA, Slice DE, Strait DS, Dechow PC, Richmond BG, Spencer MA. 2005. Modeling masticatory muscle force in finite element analysis: sensitivity analysis using principal coordinates analysis. Anat Rec 283:288-299.

Ross CF, Iriarte-Diaz J, Nunn CL. 2012. Innovative approaches to the relationship between diet and mandibular morphology in primates. Int J Primatol 33:632-660.

Roulet JF. 1987. Degradation of dental polymers. Basel: Karger.

Rubin CT, Lanyon LE. 1984. Dynamic strain similarity in vertebrates: an alternative to allometric limb bone scaling. J Theor Biol 107:321-327.

Rubin CT, McLeod KJ, Gross TS, Donahue HJ. 1991. Physical stimuli as potent determinants of bone morphology. In: Carlson DS, Goldstein SA, editors. Bone biodynamics in 
orthodontic and orthopedic treatment. Craniofacial growth series, Vol. 27. Ann Arbor: Center for Human Growth and Development, University of Michigan. p 75-91.

Rubin CT, McLeod KJ, Bain SD. 1990. Functional strains and cortical bone adaptation: epigenetic assurance of skeletal integrity. J Biomech 23:43-54.

Rubin CT, Bain SD, McLeod KJ. 1992. Suppression of the osteogenic response in the aging skeleton. Calcif Tissue Int 50: 306-313.

Rubin CT, Seeherman H, Qin Y-X, Gross TS. 2013. The mechanical consequences of load bearing in the equine third metacarpal across speed and gait: the nonuniform distributions of normal strain, shear strain, and strain energy density. FASEB J fj.12-216804.

Rudwick MJS. 1964. The inference of function from structure in fossils. Br J Philos Sci 12: 91-105.

Sayers K, Lovejoy CO. 2008. The chimpanzee has no clothes. A critical examination of Pan troglodytes in models of human evolution. Curr Anthropol 49:87-114.

Schubert BW, Ungar PS, DeSantis LRG. 2010. Carnassial microwear and dietary behaviour in large carnivorans. J Zool 280: 257-263.

Scott JE, Eastman MM, Hlavaty J, Mancini AG, Murray D, Scollan JP, McAbee KR, Ravosa MJ. 2013. It's the time of the season for extra chewing: temporal variation in diet and phenotypic plasticity in masticatory elements. Am J Phys Anthropol S56:248.

Scott RS, Ungar PS, Bergstrom TS, Brown CA, Grine FE, Teaford MF, Walker A. 2005. Dental microwear texture analysis reflects diets of living primates and fossil hominins. Nature 436:693-695.

Scott RS, Ungar PS, Bergstrom TS, Brown CA, Childs BE, Teaford MF, Walker A. 2006. Dental microwear texture analysis: technical considerations. J Hum Evol 51:339-349.

Scott RS, Teaford MF, Ungar PS. 2012. Dental microwear texture and anthropoid diets. Am J Phys Anthropol 147: $551-579$.

Scott GR, Winn J. 2011. Dental chipping: contrasting patterns of microtrauma in Inuit and European populations. Int $J$ Osteoarchaeol 21: 723-731.

Shea BT. 1986. Ontogenetic approaches to sexual dimorphism in anthropoids. Hum Evol 1:97-110.

Sponheimer M, Lee-Thorp JA.1999. Isotopic evidence for the diet of an early hominid, Australopithecus africanus. Science 283:368-370.

Sponheimer M, Lee-Thorp JA. 2001. The oxygen isotope composition of mammalian enamel carbonate: a case study from Morea Estate, Mpumalanga Province, South Africa. Oecologia 126:153-157.

Sponheimer M, Lee-Thorp JA, de Ruiter D, Codron D, Codron J, Baugh A, Thackeray JF. 2005. Hominins, sedges and termites: new carbon isotope data for the Sterkfontein Valley. J Hum Evol 48:301-312.

Sponheimer M, Passey BH, de Ruiter DJ, Guatelli-Steinberg D, Cerling TE, Lee-Thorp JA. 2006. Isotopic evidence for dietary variability in the early hominin Paranthropus robustus. Science 314:980-982.

Stearns SC. 1989. The evolutionary significance of phenotypic plasticity. BioScience 39:436-445.

Strait DS, Grine FE, Moniz MA. 1997. A reappraisal of early hominid phylogeny. J Hum Evol 32:17-82.

Strait DS, Grine FE. 2001. The systematics of Australopithecus garhi. Ludus Vitalis 9:109-135.

Strait DS, Grine FE. 2004. Inferring hominoid and early hominid phylogeny using craniodental characters: the role of fossil taxa. J Hum Evol 47:399-452.

Strait DS, Wang Q, Dechow PC, Ross CF, Richmond BG, Spencer MA, Patel BA. 2005. Modeling elastic properties in finite element analysis: How much precision is needed to produce an accurate model? Anat Rec 283:275-287.

Strait DS, Wright BW, Richmond BG, Ross CF, Dechow PC, Spencer MA, Wang Q. 2008. Craniofacial strain patterns during premolar loading: implications for human evolution. In:
Vinyard CJ, Ravosa MJ, Wall CE, editors. Primate craniofacial function and biology. New York: Springer. p 149-198.

Strait DS, Weber GW, Neubauer S, Chalk J, Richmond BG, Lucas PW, Spencer MA, Schrein C, Dechow PC, Ross CF, Grosse IR, Wright BW, Constantino P, Wood BA, Lawn B, Hylander WL, Q Wang, Byron C, Slice DE, Smith AL. 2009. The feeding biomechanics and dietary ecology of Australopithecus africanus. Proc Natl Acad Sci USA 106: 2124-2129.

Strait DS, Grosse IR, Dechow PC, Smith AL, Wang Q, Weber GW, Neubauer S, Slice DE, Chalk J, Richmond BG, Lucas PW, Spencer MA, Schrein C, Wright BW, Byron C, Ross CF. 2010. The structural rigidity of the cranium of Australopithecus africanus: implications for diet, dietary adaptations, and the allometry of feeding biomechanics. Anat Rec 293: 583-593.

Strait DR, Weber GW, Constantino P, Lucas PW, Richmond BG, Spencer MA, Dechow PC, Ross CF, Grosse IR, Wright BW, Wood BA, Wang Q, Byron C, Slice DE. 2012. Microwear, mechanics and feeding adaptations of Australopithecus africanus. J Hum Evol 62:165-168.

Stringer C. 1974. Population relationships of later Pleistocene hominids: a multivariate study of available crania. J Archaeol Sci 1:317-342.

Sugiyama T, Meakin LB, Browne WJ, Galea GL, Price JS, Lanyon LE. 2012. Bones' adaptive response to mechanical loading is essentially linear between the low strains associated with disuse and the high strains associated with the lamellar/woven bone transition. J Bone Miner Res 27:1784-1793.

Szalay FS.1975. Hunting-scavenging protohominids: a model for hominid origins. Man 10:420-429.

Tang M, Mao JJ. 2006. Matrix and gene expression in the rat cranial base growth plate. Cell Tissue Res 324:467-474.

Taylor AB. 2006. Feeding behavior, diet and the functional consequences of jaw form in orangutans, with implications for the evolution of Pongo. J Hum Evol 50:377-393.

Teaford MF. 1988. A review of dental microwear and diet in modern mammals. Scanning Microsc 2:1149-66.

Teaford MF, Glander KE. 1991. Dental microwear in live, wildtrapped Alouatta palliata from Costa Rica. Am J Phys Anthropol 85: 313-319.

Teaford MF, Glander KE. 1996. Dental microwear and diet in a wild population of mantled howling monkeys (Alouatta palliata). In: Norconk MA, Rosenberger AL, Garber PA, editors. Adaptive radiations of Neotropical primates. New York: Plenum. p 433-439.

Teaford MF, Lytle JD.1996. Diet-induced changes in rates of human tooth microwear: a case study involving stone-ground maize. Am J Phys Anthropol 100:143-147.

Teaford MF, Oyen OJ. 1989. In vivo and in vitro turnover in dental microwear. Am J Phys Anthropol 80:447-460.

Teaford MF, Robinson JG. 1989. Seasonal or ecological differences in diet and molar microwear in Cebus nigrivittatus. Am J Phys Anthropol 80:391-401.

Teaford MF, Runestad JA. 1992. Dental microwear and diet in Venezuelan primates. Am J Phys Anthropol 88:347-364.

Teaford MF, Tylenda CA. 1991. A new approach to the study of tooth wear. J Dent Res 70:204-207.

Tobias PV. 1967. The cranium of Australopithecus (Zinjanthropus) boisei. Olduvai Gorge, Vol. 2. Cambridge: Cambridge University Press.

Trinkaus E, Churchill SE, Ruff CB. 1994. Postcranial robusticity in Homo. II: Humeral bilateral asymmetry and bone plasticity. Am J Phys Anthropol 93:1-34.

Ungar PS. 2011. Dental evidence for the diets of Plio-Pleistocene hominins. Yearb Phys Anthropol 146:47-62.

Ungar PS, Grine FE. 1991. Incisor size and wear in Australopithecus africanus and Paranthropus robustus. J Hum Evol 20: 313-40.

Ungar PS, Teaford MF, Glander KE, Pastor RF. 1995. Dust accumulation in the canopy: a potential cause of dental microwear in primates. Am J Phys Anthropol 97:93-99. 
Ungar PS, Grine FE, Teaford MF. 2008. Dental microwear and diet of the Plio-Pleistocene hominin Paranthropus boisei. PLoS One 3:e2044.

Ungar PS, Scott RS, Grine FE, Teaford MF. 2010. Molar microwear textures and the diets of Australopithecus anamensis and $A u$. afarensis. Philos Trans R Soc Lond B Biol Sci 365: $3345-3354$.

van der Merwe NJ, Thackeray JF, Lee-Thorp JA, Luyt J. 2003. The carbon isotope ecology and diet of Australopithecus africanus at Sterkfontein, South Africa. J Hum Evol 44: 581-597.

van der Merwe NJ, Masao FT, Bamford MK. 2008. Isotopic evidence for contrasting diets of early hominins Homo habilis and Australopithecus boisei of Tanzania. S Afr J Sci 104: 153-155.

Van Valkenburgh B, Teaford MF, Walker A. 1990. Molar microwear in large carnivores. J Zool 222:319-340.

Vincent SE, Dang PD, Herrel A, Kley NJ. 2006. Morphological integration and adaptation in the snake feeding system: a comparative phylogenetic study. J Evol Biol 19:1545-1554.

Vinyard CJ, Ravosa MJ. 1998. Ontogeny, function, and scaling of the mandibular symphysis in papionin primates. J Morphol 235:157-175.

Vinyard CJ, Wall CE, Williams SH, Hylander WL. 2008. Patterns of variation across primates in jaw-muscle electromyography during mastication. Int Comp Biol 48:294-311.

Waddington CH. 1942. Canalization of development and the inheritance of acquired characters. Nature 150:563-565.

Waddington CH. 1953. Genetic assimilation of an acquired character. Evolution 7:118-126.

Walker AC. 1981. Dietary hypotheses and human evolution. Philos Trans R Soc Lond B 292:57-64.

Walker AC, Leakey RE, Harris JM, Brown FH. 1986. 2.5-Myr Australopithecus boisei from West of Lake Turkana, Kenya. Nature 322:517-522.

Walker AC, Leakey RE. 1988. The evolution of Australopithecus boisei. In: Grine FE, editor. The evolutionary history of the "robust" australopithecines. New York: Aldine de Gruyter. p 247-258.

Walker PL, Hagen EH.1994. A topographical approach to dental microwear analysis. Am J Phys Anthropol Suppl 18:203.

Wallace IJ, Middleton KM, Lublinsky S, Kelly SA, Judex S, Garland T, Demes B. 2010. Functional significance of genetic variation underlying limb bone diaphyseal structure. Am J Phys Anthropol 143:21-30.

Wallace JA. 1973. Tooth chipping in the australopithecines. Nature 244:117-118.

Wallace JA. 1975. Dietary adaptations of Australopithecus and early Homo. In: Tuttle R, editor. Palaeoanthropology, morphology and palaeoecology. The Hague: Mouton. p 203-223.

Weijs WA, de Jongh HJ.1977. Strain in mandibular alveolar bone during mastication in the rabbit. Arch Oral Biol 22: 667-675.

Wenzel JW, Carpenter JM. 1994. Comparing methods: adaptive traits and tests of adaptation. In: Eggleton P, Vane-Wright RI, editors. Phylogenetics and ecology. New York: Academic. p 79-101.

West-Eberhard MJ. 2003. Developmental plasticity and evolution. Oxford: Oxford University Press.

West-Eberhard MJ. 2005. Developmental plasticity and the origin of species differences. Proc Natl Acad Sci USA 102: 6543-6549.

White C, Longstaffe FJ, Law KR. 2004. Exploring the effects of environment, physiology and diet on oxygen isotope ratios in ancient Nubian bones and teeth. J Archaeol Sci 31: 233-250.

White TD, Johanson DC, Kimbel WH. 1981. Australopithecus africanus: its phyletic position reconsidered. S Afr J Sci 77: 445-470.

White TD, Asfaw B, Beyene Y, Haile-Selassie Y, Lovejoy CO, Suwa G, WoldeGabriel G. 2009. Ardipithecus ramidus and the Paleobiology of Early Hominids. Science 326:64, 75-86. DOI: $10.1126 /$ science.1175802.

Williams GC. 1966. Adaptation and natural selection. Princeton, NJ: Princeton University Press.

Wood BA, Strait DS. 2004. Patterns of resource use in early Homo and Paranthropus. J Hum Evol 46:119-162.

Wood BA, Schroer K. 2012. Reconstructing the diet of an extinct hominin taxon: the role of extant primate models. Int J Primatol 33:716-742.

Wrangham RW, Conklin-Brittain NL. 2003. The biological significance of cooking in human evolution. Comp Biochem Physiol A 136:35-46.

Wrangham R, Cheney D, Seyfarth R, Sarmiento E. 2009. Shallow-water habitats as sources of fallback foods for hominins. Am J Phys Anthropol 140:630-642. 